\title{
MIDDLE MIOCENE DIATOMITE- BEARING FORMATIONS FROM WESTERN ROMANIA
}

\author{
Codrea V. ${ }^{1}$, Barbu O. ${ }^{1}$, and Bedelean H. ${ }^{1}$ \\ ${ }^{1}$ Babeş-Bolyai University of Cluj-Napoca, Faculty of Biology and Geology, Department of \\ Geology-Paleontology,vcodrea@bioge.ubbcluj.ro, obarbu99@yahoo.com,1 Kogălniceanu \\ Str., 400074 Cluj-Napoca, Romania
}

\begin{abstract}
In Western Romania diatomite occurs only in the Lower Sarmatian (Middle Miocene) formations, as a consequence of intense volcanism developed in Apuseni Mountains and evolution of peculiar sedimentary basins connected to the Pannonian realm. The main basins with diatomite successions are Zarand and Vad Borod. The diatomite preserves besides diatoms (centric and pennate) and other microfossils (dinoflagellates, ebriidinas, silicoflagellates, phytolites) assemblages a lot of macrofossils as plants (mainly foliar imprints), fish, reptiles and mammals. Several taxa are indicative for environment reconstruction. The Lower Sarmatian climate is estimate as wet warm temperate to subtropical. A tentative of both aquatic and land environments reconstruction is done.
\end{abstract}

Key words: Sarmatian, diatomite, fossils, environment reconstruction.

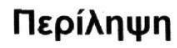

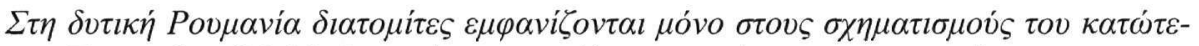

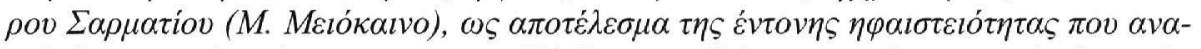

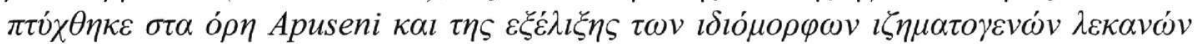

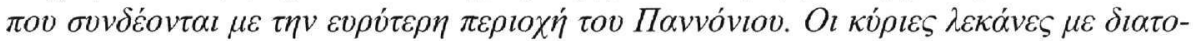

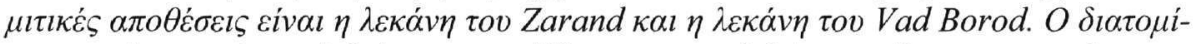

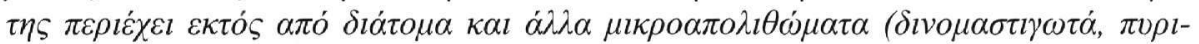

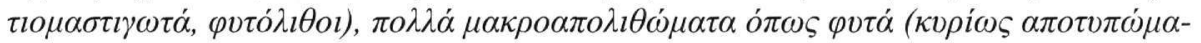

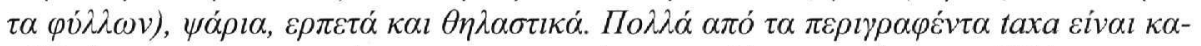

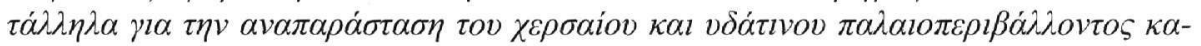

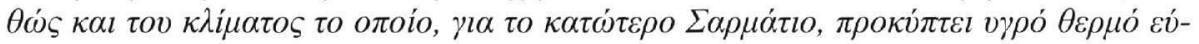

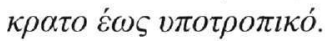

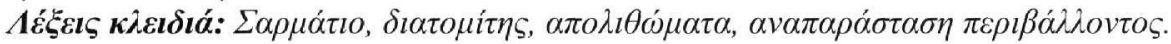

\section{Introduction}

In Western Romania, several geological events occurred in the Middle Miocene: a new generation of sedimentary basins was born and an intensive magmatic activity begun, with a paroxysmal period between 14.8-10 My (Săndulescu 1984, Roşu et al. 2000). 
A peculiar interest concern the sedimentary basins located on the western rim of the Apuseni Mountains, due to accurate data recorded into their Badenian and Sarmatian successions. Among these "gulf-basins" the Zarand Basin had a peculiar evolution: although the epoch of its genesis is nearly the same as in the other coeval basins (Şimleu, Vad-Borod, Beiuş, Mureşului passage way etc.), specific environments developed there in Sarmatian. Such an environment reffers to the Lower Sarmatian (Volhynian) tuffaceous/diatomite-bearing successions which occurred due to the intense Sarmatian volcanic activity. Sarmatian diatomites are not completely missing from the other analogous Neogene basins (e.g. Vad-Borod, Beiuş) but there one can observe only short diatomitic episodes interbedding into various other lithologies.

This contribution deals with the peculiar Lower Sarmatian depositional environments, indicating the diatom assemblages which lead to the diatomite accumulations from the Middle Miocene sedimentary basins from Western Romania.

\section{Geological setting}

The Neogene basins from Apuseni Mountains were born as eastward extensions of the Pannonian Basin since Badenian. These basins evolved as margins of the Pannonian Basin realm, where the different eustatic events marked better vestiges than elsewhere. Excepting the Şimleu Basin, the other ones are trended NW-SE or W-E, betraying older fractures inherited from the Laramian tectogenesis. Their basements involve Paleozoic and Mesozoic rocks belonging to the Inner Dacides (Săndulescu 1994, Săndulescu and Dimitrescu 2004). Over the basement, Neogene molass fills all these basins (Fig. 1).

In the Zarand Basin the Neogene deposits are of both sedimentary and volcanic origin (Istocescu 1971). The succession begin with Badenian formations (Botfei, Minişu de Sus and Mocrea; Codrea et al. 1999), followed by Sarmatian ones (Cărand, Camna, Urviş-Beliu and Paulian; Pestrea 1999). Pannonian s.str. and Pontian formations (Beliu, Hăşmaş, Prunişor, Mărăuş) remain extremely poor outlined due to the unsuitable manner of definition and scarcity of data published by Marinescu et al. (1998).

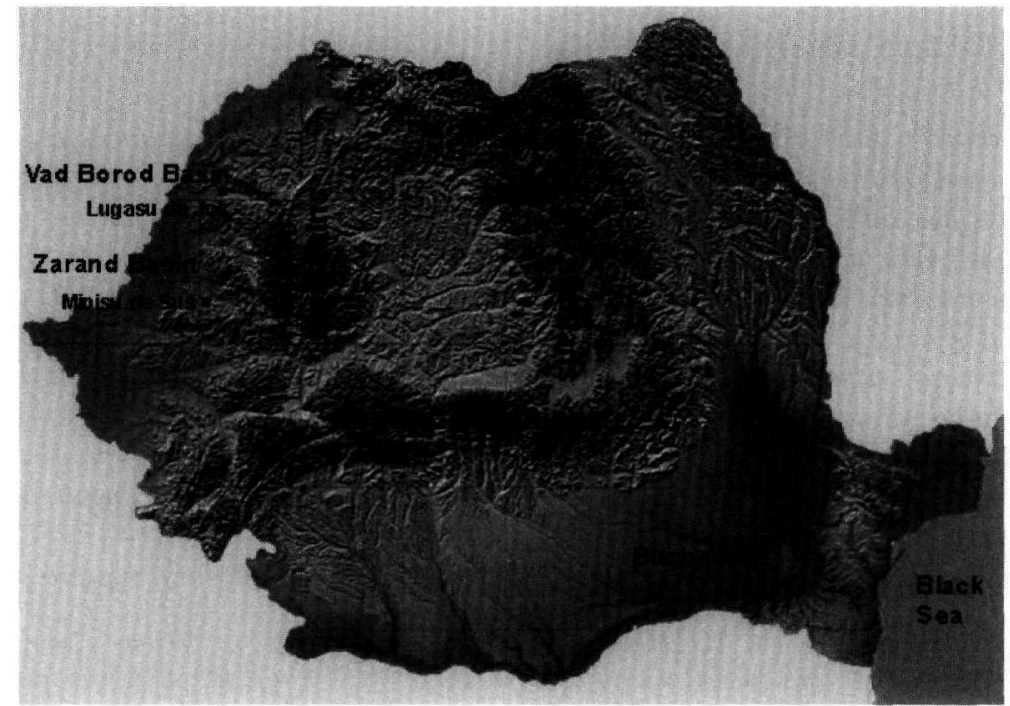

Figure 1 - Locations of the Vad-Borod and Zarand Neogene Basins in Western Romania

The Vad-Borod Basin in located northerly from Zarand. There, the Lower Sarmatian diatomite occurs only on restricted surfaces. The diatomite belongs to the Cornițel Formation (Popa 2000). However, one worth to be pointed out that the eastern sector of the Vad-Borod Basin, where Cor- 
nițel Formation is originating from, can be somehow different form the western sector, where the diatomite occur.

\section{Middle Miocene diatomite-bearing environments}

\subsection{Zarand Basin}

The diatomite occurs into the Cărand Formation as a distinct facies, which Săsăran et al. (1999) described as FA1 ("the diatomite facies") into the "diatomite-tuffaceous facies associations" (FA). The diatomite is laying unconformity on Mesozoic basement. The best diatomite exposures can be followed in the former diatomite open-pits, once mining this rock at Bârzăvița, Pârâul Nemțului or Stupii Surdului, all located in Minişu de Sus village neighbourhood. The diatomite occurs always next to the pyroclastic facies associations (FB), i.e. different tephra (lapillistones and andesite tuffs), pyroclastic breccia flows and lahar facies (Fig. 2).

In his papers Pantocsek $(1886,1889,1905)$ illustrated several diatom species and genera from different sites belonging to Cărand Formation: Minişu de Sus, Camna, Cărand and Nermiș. For Minişu de Sus, Camna and the Bremia Valley (Volume II, 1889) he referred more thoroughly to diatomites. He considered two diatomite successions to belong to brackish-water environment (Minişul de Sus, Camna) and one deposit related to a marine basin (Bremia Valley, Camna).

Later, Krestel (1970) focused her study on the Minişul de Sus diatomite and redescribed the regions previously studied by Pantocsek, but new areas too: Stupii Surdului, Dealul Râtului, Bârzăvicioara, Drânovăț, Pârâul Neamțului and Câmpul Lat. She stressed that the diatoms assemblages comprise centric mostly planktonic and generally pennate benthyic epiphytic forms. In addition to diatoms, there are also ebriidians, chrysomonads, silicoflagellates, sponge spicules and phytolites. She was considering that the diatomite from Minişu de Sus had a neritic zone genesis, in temperate climate, in Early

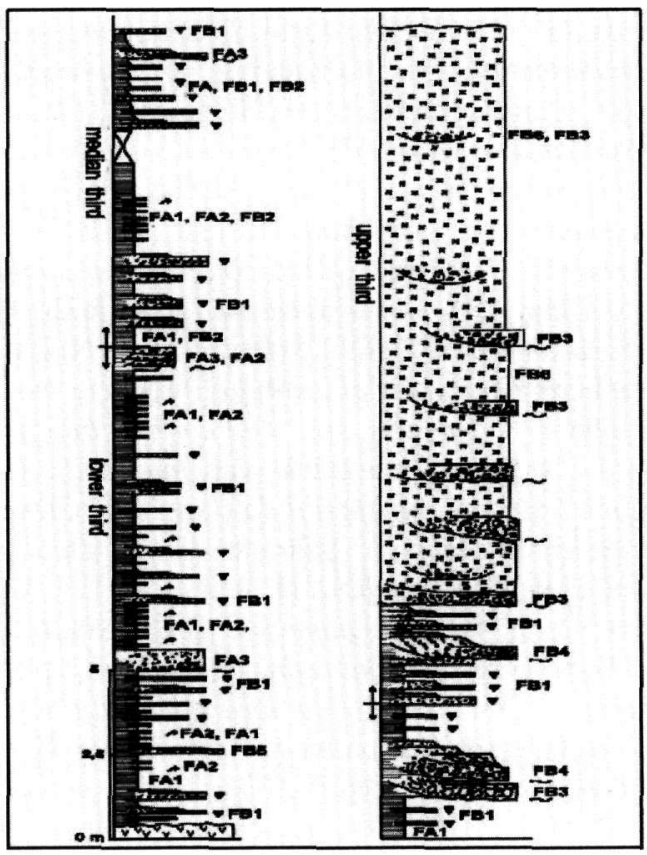

Figure 2 - Facies distribution of the Sarmatian deposits in Cărand Formation (according to Săsăran et al. 1999) Sarmatian (Volhynian).

Another study on the same diatom assemblages has been recently carried out by Pestrea (1996, 1999), describing 240 species in 66 genera. There is a preponderance of pennate forms as to the centric ones. For the Cărand profile she also established three types of associations with biostratigraphic importance from the Volhynian - Bessarabian interval.

The last contributions on the diatom assemblages belong to Barbu (2002) and Barbu and Codrea (2002).

The study we carried on stressed the following list of taxa:

DIATOMS (109 taxa: 47 centric and 62 pennate)- Melosira ambigua (Grunow) O. Muller, Melosira arenaria Moore, Melosira clavigera Grunow, Melosira rieufii Heribeaud, Melosira undulata (Ehrenberg) Kutzing, Paralia sulcata (Ehrenberg) Kutzing, Podosira hyalina Jouse, Hya- 
lodiscus constrictus (Pantocsek) Kanaya, Hyalodiscus frenguellii Hanna, Hyalodiscus scoticus (Kutzing) Grunow, Endictya oceanica Ehrenberg, Stephanopyxis schulzii Stein, Thalassosira decipiens (Grunow) Jorgensen, Coscinodiscus lineatus Ehrenberg, Coscinodiscus marginatus Ehrenberg, Coscinodiscus nitidus Gregory, Coscinodiscus oculus-iridis Ehrenberg, Coscinodiscus radiatus Ehrenberg, Coscinodiscus sarmaticus Pantocsek, Coscinodiscus subtilis Ehrenberg, Liradiscus rugulosus Forti, Xanthiopyxis leguminiformis Jouse, Xanthiopyxis ovalis Lohman, Actinoptychus reinholdii Hajos, Actinoptychus senarius (Ehrenberg) Ehrenberg, Actinoptychus splendens (Schadbolt) Ralfs, Actinoptychus undulatus (Bailey) Ralfs, Actinoptychus sp., Asteromphalus loczyi Pantocsek, Auliscus caelatus Bailey, Actinocyclus ehrenbergii Ralfs, Actinocyclus ehrenbergii var.tenella (Brebison) Hustedt, Rhizosolenia sp., Chaetoceros aculeatus Makarova, Chaetoceros affinis Lauder, Chaetoceros dentatus Korotkevicz, Chaetoceros muelleri Lemmerman, Chaetoceros subtilis Cleve, Chaetaceros sp.1, Chaetoceros sp.2, Triceratium formosum f. pentagonale A. Schmidt, Biddulphia tuomeyi (Bailey) Roper, Cerataulus sp., Pseudopyxilla capreolus Forti, Pterotheca sp., Anaulus minutus Grunow, Anaulus simplex Hajos, Gephyria media Arnott, Gephyria media f. rinnboeckii Jurilj, Rhabdonema adriaticum Kutzing, Grammatophora arctica Cleve, Grammatophora marina Kutzing, Grammatophora hamulifera Kutzing, Grammatophora robusta Dippel, Plagiogramma truanii Pantocsek, Plagiogramma sp., Dimerogramma marinum (Gregory) Ralfs, Cymatosira sp., Opephora pacifica (Grunow) Petit, Fragilaria brevistriata Grunow, Fragilaria brevistriata var. elliptica Heribeaud, Fragilaria construens (Ehrenberg) Grunow, Fragilaria construens var. subsalina Hustedt, Fragilaria construens var. venter (Ehrenberg) Grunow, Rhaphoneis debyi Pantocsek, Rhaphoneis amphiceros Ehrenberg, Rhaphoneis obesula Hanna f. trigona Hajos, Synedra parasitica (W.Smith) Hustedt, Synedra tabulata var. obtusa Pantocsek, Synedra tenera W.Smith, Synedra ulna (Nitzsch) Ehrenberg, Eunotia sp., Cocconeis placentula Ehrenberg, Cocconeis placentula Ehrenberg var. euglypta (Ehrenberg) Cleve, Cocconeis scutellum Ehrenberg, Cocconeis sp., Achnanthes baldjikii var. podolica Missuna, Achnanthes brevipes Agardh, Achnanthes brevipes var. intermedia (Kutzing) Cleve, Rhoicosphenia curvata (Kutzing) Grunow, Mastogloia splendida (Gregory) Cleve, Mastogloia aquilegiae Grunow, Dictyoneis sp., Dilponeis vacillans (A. Schmith) Cleve, Dilponeis chersonensis (Grunow) Cleve, Dilponeis sp., Anomoeoneis spaerophora (Kutzing) Pfitzer, Navicula distans (W. Smith) Ralfs, Navicula hennedyi W.Smith, Navicula humerosa Brebisson, Navicula latissima var. elongata Pantocsek, Navicula lyra Ehrenberg, Navicula placentula f. rostrata A. Mayer, Navicula pennata A.Schmidt, Pinnularia sp., Caloneis sp., Amphora gibberula Missuna, Cymbella helvetica Kutzing, Cymbella ventricosa Kutzing, Gomphonema ventricosum Gregory, Deticulopsis hustedtii Simonsen \& Kanaya, Epithemia sp., Rhopalodia gibberula var. magana (Missuna) I. Kiss, Rhopalodia musculus (Kutzing) O. Muller, Nitzschia navicularis (Breb. ex. Kutzing) Grunow, Nitzschia punctata var. aralens Borszczow, Nitzschia spectabilis (Ehrenberg) Ralfs, Suriella baltjiskii var. podolica Missuna, Camylodiscus sp.;

DINOFLAGELLATES ENDOSKELETONS - Calicipedinium quadripes Dumitircă, Carduifolia gracilis Hovasse;

EBRIIDIANS - Ammodochium rectangulare (Schultz) Deflandre, Hermesinum schultzii Hovase, Parathranium sp., Podamphora sp.;

SILICOFLAGELLATES - Distephanus crux Ehrenberg, Deflandriocha sp.; chrysomonads - Archaeomonas sp.1, Archaeomonas sp.2; sponge spicules (which are very frequently found and are 3-4 $\mathrm{mm}$ in);

PHYTOLITES - Lithostylidium parasp., Lithomestites clepsammidium (Ehrenberg) Deflandre, Lithomestites parasp.1, Lithomestites parasp.2, Lithostylidium biconcavum Ehrenberg, Lithodontiumum parasp.

Out of the total number of taxa, $58.1 \%$ originated from marine environments, $16.2 \%$ from marine-brackish ones, $4.1 \%$ from brackish ones, $8.1 \%$ from both brackish and fresh water ones and $13.5 \%$ from fresh water. 
Although the presence of different diatom taxa is not uniformly distributed within the profiles, two large types of assemblages can still be pointed out.

The first one involves the preponderance of pennate diatoms with dominance of Fragilaria and Navicula genera, next to Cymbela, Cocconeis, Synedra. The centric diatoms that can be mentioned are mainly Melosira ambigua and $M$. arenaria. This assemblage is indicative for brackish environment. It includes not only diatoms but also: chrysomonads and numerous sponge spicules.

The second assemblage is completely different from the first one, comprising other genera of centric and pennate diatoms. Its peculiarity involves the following taxa: Paralia sulcata, Coscinodiscus, Actinoptycus, Chaetoceros, Grammatophora, Plagiograma, Mastogloia and Navicula, all indicating a marine-brackish environment. There are many Coscinodiscus and Chaetoceros species the latter being extremely abundant - as well as Navicula ones too. In addition to diatoms, there are also new groups of siliceous representatives such as: silicoflagellates, ebriidians and dinoflagellates.

The distribution of these assemblages along the succession is irregular: the brackish water diatom assemblage is dominating almost in the whole sequence, with some qualitative and quantitative variation from one level to another, whereas the marine-brackish diatom one occurs only in four restricted levels within the profile.

Some index species as Anaulus simplex, Coscinodiscus sarmaticus, etc. have a wide regional extension, e.g. the Czech Republic, Slovakia, Croatia, Hungary, Bulgaria, led to the conclusion that the studied deposits can be included within the Anaulus simplex (Hajos 1986, 1990) zone of the Lower Sarmatian (Volhynian).

As compared with the previous studies 15 new genera were identified: Paralia, Endictya, Auliscus, Cerataulus, Anaulus, Plagiogrammma, Eunotia, Mastogloia, Dictyoneis, Anomoeoneis, Gomphonema, Denticulopsis, Epithemia, Surirella and Campylodiscus with 27 species, forms and varieties.

Two genera were pointed out for the silicoflagellates and erbidians: Deflandriocha and Podamphora. We should mention a novelty for this area, the presence of dinoflagellates: two species had been identified: Carduifolia gracilis Hovase and Calicipedinium quadripes.

In addition to the microflora one can mention some other elements allowing the reconstruction of the Lower Sarmatian paleoenvironment. Some of them refer to taxa originating into the basin water assemblages, as fish (mostly clupeids) or dolphins (probably Kentriodontidae representatives) (Codrea et al. 1991a, b). Sometimes, during the fresh water episodes, turtles as Trionyx stiriacus Peters occurred too (Vremir et al., 1997). The turtle remains could also be buried into diatomite as a result of rework of their carcases from the surrounding areas, carried into the basin by the river streams. A tentative of reconstruction of the Lower Sarmatian water life is illustrated in Fig. 3.

The emerged environments bordering the basin are documented either by macroflora, or by the vertebrates (Fig. 4).

The macroflora, when it occurs is very well preserved, either as foliar imprints or silicified truncks fragments. The following taxa had been collected from the diatomite or pyroclasts: Cystoseirites partschi Sternberg, Fucus sp.1, Fucus sp.2, Pteris radobojana Unger, Glyptostrobus europaeus (Brongniart) Unger, Thuja sp., Pinus sp. aff. Pinus taedaeformis (Unger) Heer, Pinus sp.- ace quaternae, Pinus sp., ex. gr. quinae Beissner- type 1, Pinus sp., ex gr. quinae Beissner- type 2, Daphnogene polymorpha (Al. Br.) Ettingshausen, Lindera antiqua (Heer) Givulescu \& Barbu, 


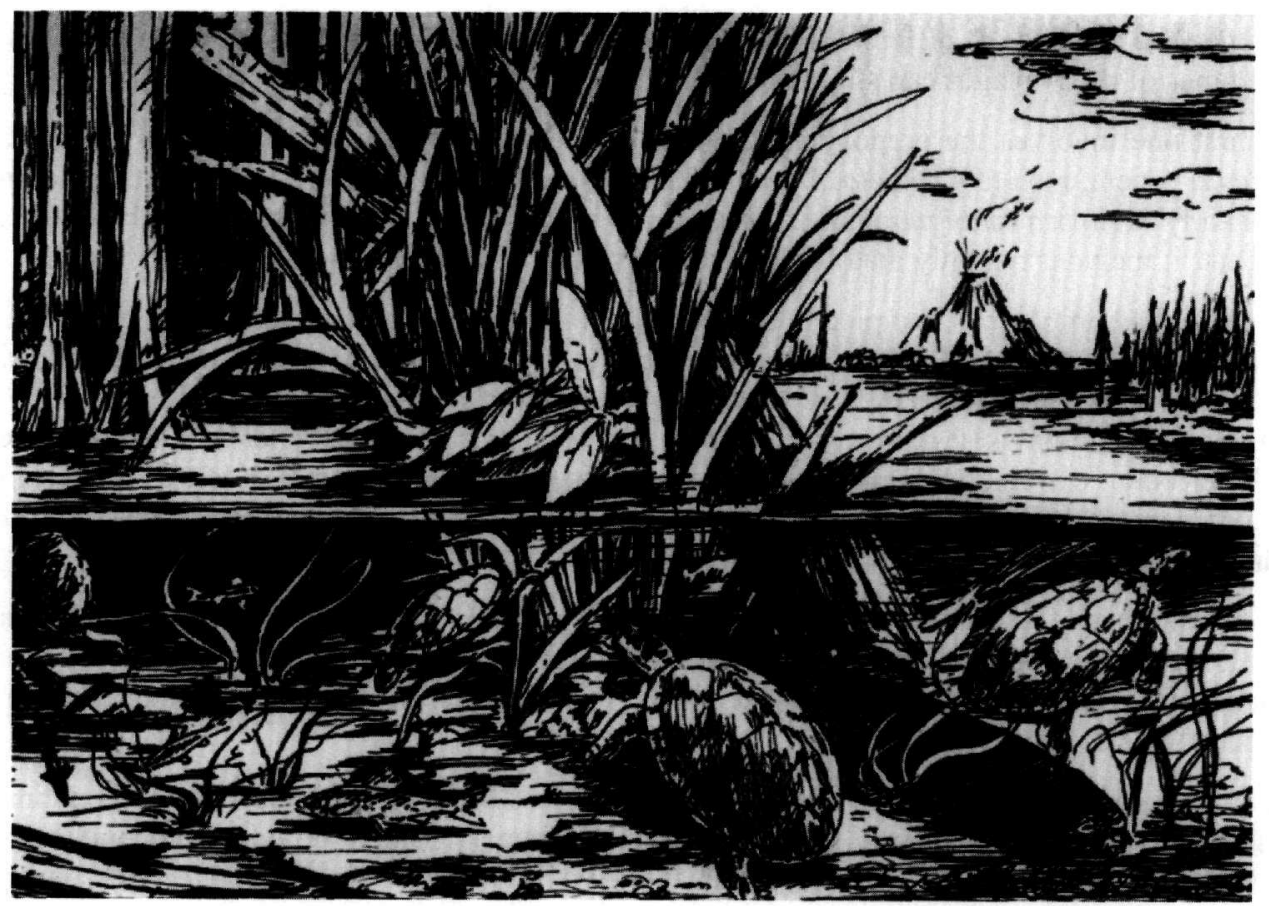

Figure 3 - Reconstruction of the Lower Sarmatian aquatic environment at Minişu de Sus (drawing by Flaviu Săsăran)

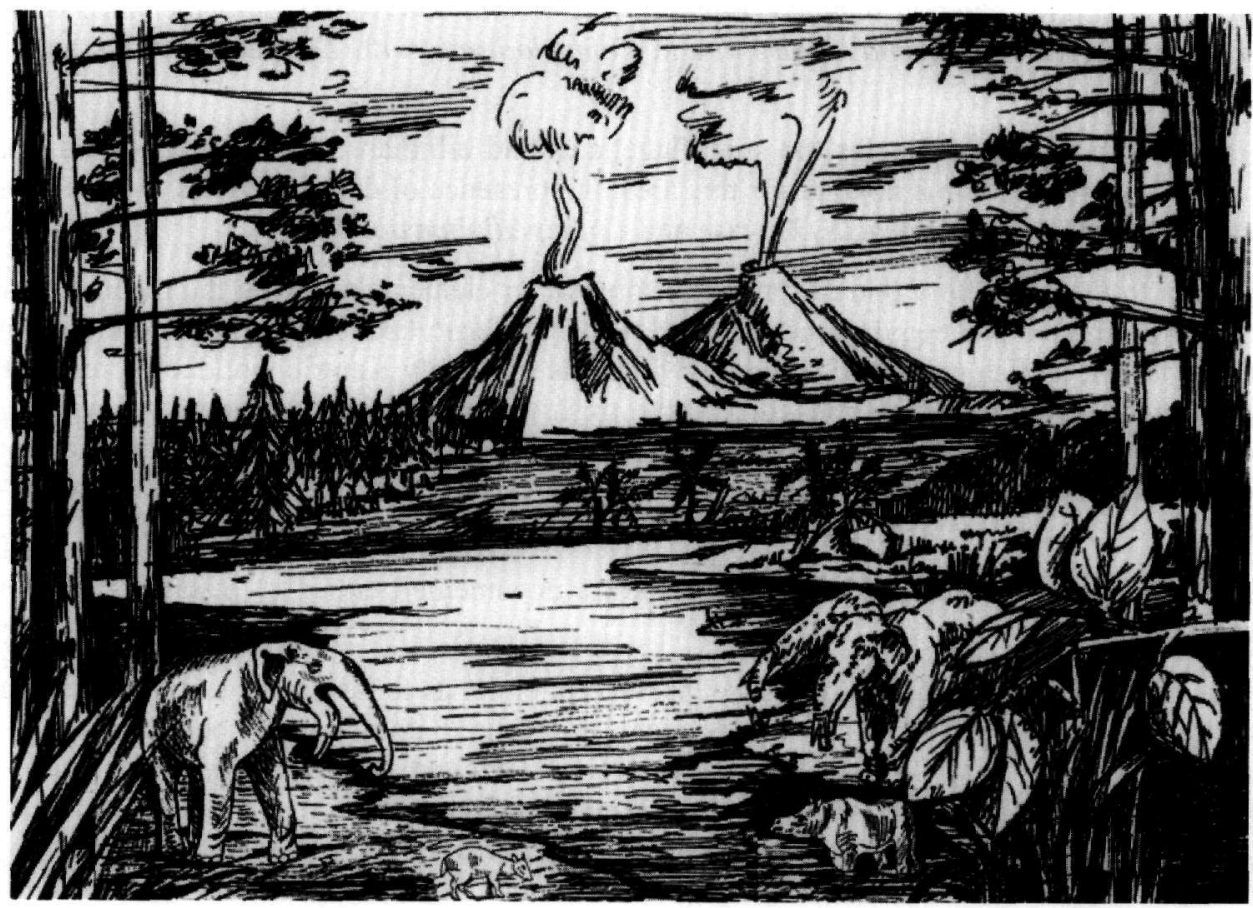

Figure 4 - Reconstruction of the Lower Sarmatian land environment at Minişu de Sus (drawing by Flaviu Săsăran)

Laurophyllum braunii (Heer) Nemejc \& Knobloch, Laurophyllum ? sp., Platanus leucophylla (Unger) Knobloch, Quercus cf. ilex Linné, Quercus sp. or Castanea sp., Myrica lignitum (Unger) 
Saporta, Myrica vindobonensis (Ettingshausen) Heer, Carya denticulata (Weber) Iljinskaia, Acacia parschlugiana Unger, Cassiophyllum berenices (Unger) Krausel, Gleditsia lyelliana (Heer) Hantke, Gleditsia knorii (Heer) Gregor, Zanthoxylon europaeum Unger, Rhus prisca Ettingshausen, Populus populina (Brongniart) Knobloch, Chamaerops humilis Linné fossilis Kolakovski, Dicotylophyllum sp.1, Dicotylophyllum sp.2, Dicotylophyllum sp.3. (Givulescu et al. 1995, 2002).

This typically Sarmatian flora is in complete concordance with the other Early Sarmatian floras from Transylvania. It belongs to the type flora with Cystoseirites, but without Palaeocarya, an element which has not been stressed up to the present stage of our research (Givulescu 1992).

The taphocaenosis is not very rich. The fossils are made up of having been brought from the surrounding land areas at different moments and, as we shall show later, from various different assemblages.

From a statistic point of view, within this flora there are: 16 families with 20 genera and 24 species +3 uncertain ones. Therefore, it is a flora with a low number of samples, but still sufficiently rich in families and genera. It is also worth mentioning that, out of the identified forms, 10 are arctotertiary, 6 palaeotropical, i.e. $62.50 \%: 37.50 \%$; there are 15 trees and 7 shrubs, i.e. $68.18 \%$ : $31.82 \%$; we found 9 types with dentate leaves and 7 with whole margin leaves, i.e. $56.25 \%$ : $42.75 \%$.

We should point out as a significant fact the presence of a palm tree in the Early Sarmatian, Chamaerops humilis fossilis (Givulescu and Barbu 1999). The remaining flora is common for the Early Sarmatian. Anyway, we are also stressing Lindera antiqua, and Quercus $\mathrm{cf}$. ilex, which had their first appearance datum in the Transylvanian floras, just like Carya denticulata. On the other hand, Myrica vindobonensis and Acacia parschlugiana are relicts, because they are peculiar to the Early Miocene and Oligocene. It is very interesting to note the numerous Pinus types and the discovery of a Pinus with quaternae needles.

The foliar remnants belong to several environments. Putting aside the brackish water environment with Cystoseirites, two categories can be distinguished on the surrounding basin land: one of flooded swamps with Glyptostrobus, Gleditsia, Myrica, Platanus, probably Pinus taedaeformis and maybe even Carya; another with drier areas with Lauraceae, other vegetables and especially Chamaerops and Quercus cf. ilex., which forms assemblages even in actual occidental Mediterrean region. The shurb Zanthoxylon as well as the fern Pteris were also present too.

The Early Sarmatian climate had been estimate on the percentage of whole margin leaves. One can presume a subtropical wet climate (Cfa sensu Koppen) or according to Dilcher (1973), a wet or even very wet warm temperate one.

For over a decade of field missions a sample of Sarmatian land vertebrate fossils have been collected. It concerns mammals, as water-chevrotain (Dorcatherium crassum (Lartet)), listriodon (Listriodon splendens splendens Von Meyer), a small rhino (Alicornops simorrense (Lartet)), dinothere (Deinotherium giganteum Kaup) and mastodon (Gomphoterium angustidens (Cuvier)) (Nicorici 1976, Codrea et al. 1991 a, b, Codrea 1992, 1996). In addition, an Anchitherium calcaneum exists in the collection of the Hungarian Geological Istitute (MAFI) in Budapest (unpublished). The whole assemblage can be related to the $\mathrm{MN} 7+8$ unit, i.e. the terminal Astaracian.

In order to understand the context in which diatomite sediments were laid, we should refer to the Volhynian palaeogeography of this area. After the low marine level tendency which happened at the end of the Late Badenian, in Volhynian there were ingressive tendencies due to which the Zarand area turned into an archipelago belonging to the Central Paratethys. The surface covered by the Sarmatian waters overcame the Badenian one. In this manner the Sarmatian happen to lye in unconformity over the Permo-Mesozoic basement. 
The large mammals and the macroflora, both are evidence for the processes taking place on land environments. The macroflora remnants show that the coasts were dense forested areas, where Anchitherium-type fauna occurred. The presence of Listriodon as well as that of Dorcatherium is evidence in this respect. Water-chevrotain seems to account for the presence of gallery-forests, just like Alicornops simorrense which could even be indicative for swamps, also documented by Glyptostrobus europaeus, Myrica lignitum, M. vindobonensis, Glaeditsia lyelliana etc.

As a conclusion, mainly the diatomite assemblages indicate that at Minişu de Sus only the Volhynian can be proved, a different situation compared to the Carand site, where Pestrea (1999) found the Bessarabian too.

\subsection{Vad-Borod Basin}

The small diatomite outcrops we have studied from the Cornițel Formation (Popa 2000) are located near Lugașu de Jos, ten km westward from Aleșd town. The succession is analogous with the one from Minişu de Sus, with diatomite interbedding in tuff. There, Pantocsek $(1886,1889,1905)$ mentioned a list including 104 taxa. Among the peculiar forms, there are: Clavicula biharenisis Pantocsek, Actinocyclus circumdatus Panocsek., Actinoptychus kymatodes Pantocsek, Coscinodiscus biharensis Pantocsek., Coscinodiscus martonfi Pantocsek, Epithemia biharensis Pantocsek., Melosira biharensis Pantocsek, Navicula (didyma Ehrbg. var.?) elesdiana Pantocsek, Navicula halionata Pantocsek, Navicula pseudofusca Pantocsek., Plagiogramma biharense Pantocsek., Surirella (striatula Turp.?) antiqua Pantocsek, Surirella biharensis Pantocsek, Surirella rotunda Pantocsek, Triceratium (acutangulum Grev. var.?) grovei Pantocsek, Triceratium (antillarum Clev. var.?) laetum Pantocsek, Triceratium polygibbum Pantocsek. As one can observe, all were new species described by Pantocsek.

From the diatomite, leaf imprints as well as fish skeletons had been collected. The macroflora comprises: Daphnogene polymorphum (Braun) Ettingshausen, Tetraclinis salicornioides (Unger) Kvacek and Myrica lignitum (Unger). They prove the same climate as at Minişu de Sus. The fish are represented by skeletons and otoliths belonging to Blennius sp., Gobius sp., Dapalis sp., Prolebias sp., Pomatoschistus triangularis (Weiler), Acentrogobius sp., Prolebias senesi Brzobobathy and Stancu. According to the number of fish vertebra, the basin had brackish waters, probably $29 \%$. Considerable amount of fresh water probably come into the basin as an input carried on by the river streams.

\section{Conclusions}

In the Western Apuseni Middle Miocene sedimentary basins the diatomite occurs as consequence of the Neogene volcanism, in Sarmatian. All this kind of basins was related to the great Pannonian Basin realm, since the Badenian. The main diatomite sequences can be followed in Zarand and Vad Borod basins. However, thiner diatomite episodes can occur also in the other analogous basins from Western Romania.

All this diatom assemblages (centric and pennate) as well as the micro organisms occurring besides (dinoflagellates, ebriidinas, silicoflagellates, phytolites) formed rocks which afforded exceptional fossilisations. Leaf imprints, fragments of siliceous woods, bones and teeth of fish, reptiles or mainly large mammals had been collected from the different outcrops. Several taxa are good markers for the Sarmatian environment reconstructions. The Lower Sarmatian (Volhynian) landscape in both in Zarand and Vad-Borod basins concerned dense forested areas, sometimes with swampy tendencies, in a wet warm temperate climate. The vertebrate fauna belongs to final Astaracian, i.e. $\mathrm{MN} 7+8$ unit. The rims of the Sarmatian basin crossed several salinity changes. The brackish water dominance had been interrupted by fresh water episodes, documented by different diatom assemblages. 
Several decades, mining had been carried on for the Western Romania Sarmatian diatomite (Brana 1967). The reserves there are still important and would legitimate the continuation of mining mainly in Zarand Basin.

\section{Acknowledgements}

We address our thanks to our friend Flaviu Săsăran a full gifted artist who helped us in our tentatives in reconstructing the Sarmatin environment at Minişu de Sus. A lot of colleagues form Babeş-Bolyai University Cluj-Napoca gave us their competence proof in interpreting the Sarmatian from Western Romania: Acad. Răzvan Givulescu, Prof. Dr. Iustinian Petrescu, Senior lecturer Dr. Emanoil Săsăran. We are thankful to all. Special thanks to Prof. Dr. László Kordos for his hospitality and collegial help during our visits in Budapest at the Hungarian Geological Institute (M.A.F.I).

\section{References}

Barbu, O., 2002. Asociații de diatomee şi alte microorganisme silicioase din depozitele sarmațiene inferioare din cariera Bârzăvița II, jud. Arad., Armonii Naturale, IV, 65-70.

Barbu, O., and Codrea, V., 2002. Additional taxa within the siliceous microfloristic assemblages from the Bârzâvița II quarry (Arad county, Romania), Studia Universitatis Babeş-Bolyai, Biologia, XLVII, 2, 11-14.

Brana, V., 1967. Zăcăminte nemetalifere din România. Editura tehnică, 472pp.

Codrea, V., 1992. New mammal remains from the Sarmatian deposits at Minişu de Sus (Tauț, Arad county), Studia Universitatis Babeş-Bolyai, Geologia, 37/2, 35-41.

Codrea, V., 1996. Additional data concerning the Early Sarmatian Listriodontinae of Minişu de Sus, Studia Universitatis Babeş-Bolyai, Geologia, 41/2, 93-101.

Codrea, V., Laslo-Faur, and Al., Dudaş, C., 1991a. Gigantic suid: Listriodon aff. lockharti (Pomel) from the Sarmatian Diatomitic-Tuffaceous Complex at Minişu de Sus (Tauț, Arad District). In The Volcanic Tuffs from the Transylvanian Basin: 93-102pp.

Codrea, V., Laslo-Faur, Al., Dudaş, C., Hosu, Al., and Barbu, O., 1991b. The first Romanian record of Deinotherium levius JOURDAN from the Sarmatian Diatomitic-Tuffaceous Complex at Minişu de Sus (Tauț, Arad District). In The Volcanic Tuffs from the Transylvanian Basin: 103-109pp.

Codrea, V., Barbu, O., and Săsăran, E., 1999. Contributions to the nomenclature of the Badenian succession from the Crişul Alb Depression, Studia Universitatis Babeş-Bolyai, Geologia, XLIV (2), 119-124.

Dilcher, D., L., 1973. Paleoclimatic interpretation of the Eocene floras of Soutestern North America. In Vegetation and Vegetation History of Northern Latin America, Elsevier, 39-59.

Givulescu, R., 1992. Considerations on the Sarmatian floras of Transylvania, Romanian Journal of Paleontology, 75, 47-59.

Givulescu, R., Barbu, O., and Codrea, V., 1995. New Plants from the Volhynian Diatomites at Minişu de Sus, Studia Universitatis Babeş-Bolyai, Geologia, 40/2, 63-68.

Givulescu, R., and Barbu, O., 1999. Eine fossile Palmae Chamaerops hummilis Linné fossilis Kolakovski aus dem Miozän von Rümanien, Beitrage zur Paläontologie, 24, 87-90.

Givulescu, R., Barbu, O., and Codrea, V., 2002. The Sarmatian Flora from Minișu de Sus, Romania. Documenta naturae, $144,35 \mathrm{pp}$. 
Hajos, M., 1986. Stratigraphic position of Miocene Diatom and Silicoflagellate Zones in the Central Paratethys. In $9^{\text {th }}$ Diatom Symposium, 181-196pp.

Hajos, M., 1990. Succession of the fossil diatom floras in the Carpathian Basin, Hungary, Nova Hedwigia, 100, 227-236.

Istocescu, D., 1971. Studiul geologic al sectorului vestic al bazinului Crişului Alb şi ramei Munților Codru şi Highiş, Institutul Geologic, Studii tehnice şi economice, Seria J, 8, $201 \mathrm{pp}$.

Krestel, S., 1970. Studiul micropaleontologic al diatomitelor din Republica Socialistă România, Rezumatul Tezei de doctorat, Universitatea din Bucureşti, 28pp.

Marinescu, Fl., Mărunțeanu, M., Papaianopol, I., and Popescu, Gh., 1998. Tables with the correlation of the Neogene deposits in Romania, Romanian Journal of Stratigraphy, 78, 181-186.

Nicorici, E., 1976. Trilophodon angustidens (Cuvier) din Sarmaţianul inferior de la Minişul de Sus (bazinul Zarandului), Dări de Seamă ale Institutului de Geologie şi Geofizică, 62(3), 77-79.

Pantocsek, J., 1886. Beitrage zur Kenntnis der Fossilen Bacillarien Ungarns. Theil I, 1886: Marine Bacillarien. Nagy-Tapolcsany, Julius Platzko 76pp.

Pantocsek, J., 1889. Beitrage zur Kenntnis der Fossilen Bacillarien Ungarns. Theil II, 1889: Brackwasser Bacillarien, Nagy-Tapolcsany, Julius Platzko, 123pp.

Pantocsek, J., 1905. Beitrage zur Kenntnis der Fossilen Bacillarien Ungarns. Theil III: Beschreibung neuer Bacillarien welche in der Pars III der "Beitrage zur Kenntnis der Fossilen Bacillarien Ungarns abgebildet wurden”, Pozsony, C.F. Wigand, 118pp.

Pestrea, S., 1996. Comparative Sarmatian diatom assemblages from Getic and Zarand areas and their paleogeographic and paleoecologic implications, Anuarul Institutului Geologic al României, 69 (I), 140-143.

Pestrea, S., 1999. Studiul diatomeelor sarmațiene din România, Teză de doctorat, Universitatea din Bucureşti, 32pp.

Popa, M., 2000. Lithostratigraphy of the Miocene deposits in the Eastern part of Borod Basin (North-Western of Romania), Studia Universitatis Babeș-Bolyai, Geologia, 45/2, 93-103.

Roşu, E., Panaoitu, C., Pecskay, Z., Panaiotu, C., E., and Ivăşcanu, P., E., 2000. Neogene magmatism in the Apuseni Mountains. Evolution and geochemical features, Anuarul Institutului Geologic al României, 72, Special Issue, 71-72.

Săndulescu, M., 1984. Geotectonica României. Editura Tehnică, 336pp.

Săndulescu, M., 1994. Overview on Romanian Geology, Romanian Journal of Tectonics and Regional Geology, 75, 2, 3-15.

Săndulescu, M. and Dimitrescu, R., 2004. Geological Structure of the Romanian Carpathians, $32^{\text {nd }}$ International Geological Congress, Field Trip Guide Book-B12, 1, 3-18.

Săsăran, E., Codrea, V. and Barbu, O., 1999. Facies assemblages and architecture of the sedimentary environments from the Cărand Formation (Sarmatian) in the Zărand Depression (Western Romania), Studia Universitatis Babeş-Bolyai, Geologia, 44 (2), 103-117.

Vremir, M., Codrea, V., and Farkas, B., 1997. Trionyx stiriacus Peters, 1855 (Reptilia, Testidines) from the Sarmatian (Middle Miocene) of Minișu de Sus (Romania), Annales HistoriumNaturalis Museis Nationalis Hungarici, 89, 43-52. 